\title{
The technical efficiency of military industrial enterprises: A civil-military integration perspective
}

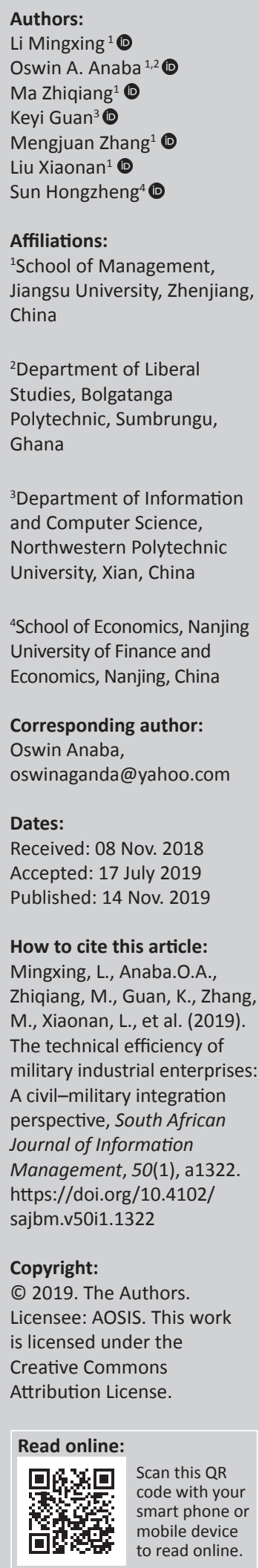

\section{Copyright:}

C 2019. The Authors. Licensee: AOSIS. This work is licensed under the Creative Commons Attribution License.

\section{Read online:}

Background: This article takes a look at the technical efficiency of 53 A-share listed companies of Chinese military industrial enterprises in the '10 Major Military-industrial Groups' based on the random Frontier B95 model and the panel data of listed companies from 2010 to 2015.

Objectives: The research put forward five influencing factors, namely ownership structure, asset turnover, enterprise size, staff education and regional differences.

Method: The article proposed five hypotheses to measure the technical efficiency of the military and civilian enterprises.

Results: The results showed a gradual increase in the technical efficiency of sampled military industrial enterprises, even though the overall results were low with a decreasing scale income. There was a positive correlation between ownership concentration and the technical efficiency of military industrial enterprises, but not significant. However, the proportion of state-owned large shareholders and the technical efficiency of military industrial enterprises had a negative correlation and were not significant. Asset turnover ratio, firm size, employee education level and regional differences correlated positively with the technical efficiency of military industrial enterprises, and their influence was seen to be very important.

Conclusion: The conclusion of the study provides an empirical basis for further studies enhancing the technical efficiency of military industrial enterprises in China.

Keywords: Military enterprises; technical efficiency; SFA model; influencing factors; listed enterprises; civil-military integration.

\section{Introduction}

Military industrial enterprises bear the most important tasks of national defence, scientific research and production, and are engaged in providing various types of weapons and equipment to state armed forces for their research and production. Consequently, the development of military industrial enterprises may directly affect the national security. From the 'Universe Brand' weapons (weapons made by various countries) of the first parade after the founding of New China (Peoples Republic of China) to the 'Made in China' at the Tribute of 70th Centenary of the Conquest of Chinese People's Battle against Japanese Assault and the World Anti-Nazi Conflict, we can see that the military industrial enterprises in China indeed have undergone tremendous changes. In order to further accelerate the development of China's national defence and army building, the integration strategy for civil and military affairs rose to a national strategy in 2015. With the development of the military-civilian integration strategy, the '10 Major Military-industrial Groups' established in 1999 has become a distinctive military-civilian integration industry. However, because of the fact that the property rights system and the enterprise system of military industrial enterprises are not yet standardised (Jiong \& Yinning, 2012) and the higher barriers to entry in the field of national defence, science and technology, the improvement of the technical efficiency of military industrial enterprises has been restricted to a certain extent.

For the reasons stated above, this study in particular tries to delve into the efficiency of military industrial enterprises by specifically looking at five influencing factors, namely ownership structure, asset turnover, enterprise size, staff education and regional differences of the civil-military integration enterprises. This study will not only enrich the literature on military industrial enterprises but also serve as a guide for the managers and owners of civil-military integration enterprises.

Therefore, research on the technical efficiency of military industrial enterprises and the elements that affect the technical efficiency of military industrial enterprises have become particularly crucial. 
The article unfolds as follows. After this introduction, the 'Literature Review' section explains the various literature on military industrial enterprises. The methodology employed and the theoretical overview assumptions are discussed in the 'Theoretical Overview and Assumptions' section, while the research methodology used is presented in the 'Study Design and Data Description' section. The next section is the 'empirical analysis' section, followed by conclusions, implications and suggestions sections.

\section{Literature review}

Aiming at how to promote the development of military industrial enterprises against the backdrop of military and civilian integration, scholars in China and abroad have conducted a great deal of research, both quantitatively and qualitatively. On the qualitative aspect, Jun (2004) studied and designed the rating index system and the evaluation method of the technological innovation capability of stateowned military industrial enterprises. Jun's results posited that it was necessary to establish and improve the technological innovation system to enhance technological innovation capabilities and recommended seven specific measures to be taken to ensure technological innovation. Establishing the Entropy-Tops is evaluation model of the independent innovation capability of military industrial enterprises, Hang, Guang and Bai-zhou (2013) set the evaluation index from the viewpoints of Research and Development (R\&D) capability, production ability, input ability, achievement capability and management ability. Their findings suggested that the index system had a positive influence on the military industrial enterprises and therefore provided administrative references for improving the independent innovation capability of the enterprises. Likewise, Sheng-sheng and Ye (2014) defined the connotation of the transformation and upgrading capability of military industrial enterprises and pointed out that the external environment of the enterprises, the characteristics of the top management team, the network of enterprises and the dependence of the enterprises all affect the ability of the military industrial enterprises to transform and upgrade. Based on these related theoretical models, Li and Chao-feng (2014) analysed the status quo and problems of militarycivilian integration in the nuclear energy industry from the aspects of technology integration, enterprise integration, demand integration and system integration based on the framework of industrial integration analysis. Furthermore, Tao (2015) studied the impact of the technology transfer and knowledge accumulation mechanism on the competitiveness and sustainable growth power of military and civilian integration enterprises against the background of militarycivilian integration. Based on this, the author discussed the suggestions on how to optimise the knowledge structure of military and civilian integration enterprises and enhance the growth ability of enterprises.

On the quantitative aspect, Jeong, Lee and Lee (2010) used stochastic frontier models (SFM) to analyse the influencing factors of the profitability of Korean defence enterprises and tested the hypothesis of national defence industry cost transfer based on the efficiency measurement method. Jeong et al. (2010) pointed out that the average technical efficiency of the defence part was not significantly higher than the commercial part. Additionally, Jiong (2012) selected a panel data of 52 military-listed companies from 2008 to 2010 and used a multivarite linear regression model to empirically study the relationship between ownership structure and business performance of China's military-listed companies. Moreover, Yaun-jun and Lin (2016) used the Data Envelopment Analysis (DEA) model to analyse and compare the efficiency of private military and state-owned military industrial enterprises and focused on the resource allocation model, structure and efficiency of private military industrial enterprises, so as to improve the efficiency of using defence science and technology resources. Based on the generalised least squares (GLS), Zhonghua and Xiaofeng (2013) conducted an empirical analysis on the influence of technology spillovers and government subsidies on enterprise innovation behaviour. The results showed that technology spillovers, government subsidies and militarylisted company's R\&D output were significantly negatively correlated. Employing the stochastic frontier analysis, Zhijun, Changhui, Zhanglin and Keyu (2015) calculated the overall efficiency of technological innovation in eight military industrial enterprises. They pointed out that military industrial enterprises should strengthen management and operation, optimise the investment structure of innovation elements and enhance awareness of innovation efficiency and technical innovation efficiency. Using the DEAMalmquist index of production to conduct a comparative analysis on the operating efficiency of state-owned and 'militia army' enterprises in 16 listed military industrial enterprises, Min and Haojie (2016) identified some problems in the development of military industrial enterprises. Using the SNG and least squares dummy variable method (LSDV), Baijie and Aijin (2016) also analysed the efficiency level of military industrial enterprises and its influencing factors (product differentiation, enterprise scale, market competition, share capital structure, equity concentration and state-owned shareholding ratio). The study found that the average technical efficiency of military industrial enterprises is only 0.459 with an annual growth rate of $3 \%$. The technical efficiency of military industrial enterprises is also positively correlated with the degree of civilisation of their products, with significant regional differences.

In summary, the research on military industrial enterprises has some limitations. Firstly, some of the research results focused on the theoretical level, which lacks empirical analysis. This is not conducive to the visual analysis of technical efficiency of enterprises in the context of militarycivilian integration, resulting in the conclusion of the lack of reliability and validity. Secondly, the empirical analysis of the influencing factors of the technical efficiency of military industrial enterprises is not comprehensive enough. In particular, there is a lack of systematic research on the influencing factors such as asset turnover, firm size, staff education level and regional differences. Therefore, this article intends to differ from other studies by selecting the ' 10 
Major Military-industrial Groups' of the 53 A-share listed companies as the research object, use the random Frontier B95 model to measure the efficiency level and analyse the efficiency of the factors that affect the development of civil-military integration in China. The results of this study will provide some meaningful inspiration and better understanding of the development of military industrial enterprises.

\section{Theoretical overview and assumptions}

The technical efficiency includes three connotations: how to maximise the output under a fixed input, what is the minimum investment under a fixed output and how to augment an inefficiency in a fixed input or output. The measure of technical efficiency was first proposed by Farrell (1957) and Afriat (1972). In the analysis of the influencing factors of technical efficiency, this article proposes the research hypothesis from the following aspects:

\section{Ownership structure}

In terms of ownership concentration, Qunying (2009) pointed out that the shareholding ratio of the largest shareholder in China's military-listed companies had a significant positive correlation with economic performance. The economic performance of the company increases exponentially with the increase of the largest shareholder. The sum of the shareholdings of the top 10 shareholders and economic performance had a positive U-shaped relationship. According to Lingxiao (2012), the concentration of ownership can have a certain impact on technological innovation in military industrial enterprises. Using the DEA model, Xiangyin, Zhonghua and Ting (2016) analysed the technical efficiency of listed Chinese eco-agriculture enterprises and considered that increasing the concentration of ownership was beneficial to reduce the waste of input redundancy and then improving the technical efficiency of listed companies. Furthermore, Kaiwen and Fanbin (2014) analysed the three-stage model and pointed out that the over-concentration of ownership led to the waste of fixed assets. Therefore, maintaining a moderate degree of ownership concentration was conducive to improving the technical efficiency of enterprises. The results of Yongmei, Qinliang, Chong, Yanming and Yuan (2015) show that the ownership concentration of listed companies in the wind power industry was positively correlated with the efficiency of innovation decision-making, which was conducive to making efficient innovation decisions and improving the technical efficiency of enterprises. The empirical analysis of Qian, Xiuyun, Yuan and Yining (2015) pointed out that ownership concentration had a positive impact on technical efficiency and moderately increased the degree of equity concentration conducive to the better development of cultural and creative enterprises. In terms of the shareholding of state-owned shares, Jianshan and Chunmi (2009) held that the state-owned holding had a negative impact on both technical efficiency and company performance. On the other hand, Zhongyong (2010) pointed out that the 'state-owned shares' represented by the shareholders of listed military industrial enterprises had a positive impact on the efficiency of enterprises. The studies of Baijie and Aijin (2016) showed that the proportion of stateowned holding in military industrial enterprises had a significant negative effect on the technical efficiency of enterprises. With the continuous advancement of the military-civilian integration strategy, China's efforts to absorb private capital into the national defence science and technology industry will profoundly affect the ownership structure of military industrial enterprises. Ownership structure, power structure and business decision-making are closely linked. The ownership structure determines the power structure, and the power structure and business decisions affect the operating structure and thus the ownership structure of the business efficiency of enterprises. Based on the above analysis, this article proposes the following assumptions:

H1: Ownership concentration has a positive effect on the technical efficiency of military industrial enterprises.

H2: The shareholding of state-owned major shareholders has a negative impact on the technical efficiency of military industrial enterprises.

\section{Asset turnover}

Based on the DEA-Tobit two-stage model, Yuhai and Kun (2010) pointed out that the total asset turnover rate and the brewery efficiency values were significantly positively correlated. Using the DEA-Tobit model based on SORMBCC and Malmquist index, Bao-Bao and Yan-Ling (2011) found that there was a significant positive relationship between asset turnover and the overall technical efficiency and scale efficiency of food and beverage companies. In addition, Mei (2013) pointed out that the total assets turnover rate was an important factor affecting the innovation performance of enterprises. Making use of the DEA-Tobit two-stage model analysis, Ying and Po (2016) showed that there exited a significant positive effect between total asset turnover and business performance of the listed companies in China's sports industry. Military industry is a special industry, in which technology has a certain advanced feature. The asset turnover rate can show the product recognition from market, thus indicating that the turnover of assets affects the technical efficiency of enterprises in the military industry. Based on the above analysis, this article proposes the following assumption:

H3: Asset turnover has a positive effect on the technical efficiency of military industrial enterprises.

\section{Enterprise size}

Taking the power generation industry as the research object, Feng, Jian-wan and Shun-xian (2008) pointed out that in the case of too low an output level, there was no scale income. Only when the scale exceeds a critical point, technical efficiency increases with the expansion of scale, that is, there is a ' $U$ ' relationship between firm size and technical efficiency. Based on SORM-BCC and DEA-Tobit model, Bao-Bao and 
Yan-Ling (2011) held that the size of the business also had a positive impact on the technical efficiency in China's food and beverage companies. Besides, Ran and Yue (2015) pointed out that the modest expansion of SMEs can enhance the technical efficiency. Large-scale enterprises will have economies of scale because of the advantages of attracting talents, cost sharing and better reputation, thereby reducing the risks in the production and operation process and thus affecting their technical efficiency. Based on the above analysis, this article proposes the following assumption:

H4: Firm size has a positive effect on the efficiency of military technology.

\section{Staff education}

Based on the DEA-Tobi two-stage model, Jianyue and Kongjiao (2013) held that the educational level of employees can cause a positive shift in technical efficiency in listed aquaculture companies. Yuanyuan (2013) indicated that there is a significant positive correlation between employee education and the efficiency of automobile enterprises in listed companies in China's automobile industry, that is, the technological efficiency of enterprises increases with the improvement of employees' education level. Likewise, Wenjun and Bing (2016)pointed out that employee education had a very significant positive impact on the technical efficiency of China's listed steel companies. Employees are the main body of the business operations of the enterprise. At the same time, the educational level of employees is an indicator to measure the quality of employees. The educational level of employees determines the quality of human capital, which affects the technical efficiency of enterprises. Based on the above analysis, this article proposes the following assumptions:

H5: Employee education has a positive effect on military technical efficiency.

\section{Regional differences}

After analysing the technical efficiency of 30 provinces in China, the results of Chunyan, Chen, and Zhaoyang (2014) indicated that there were obvious differences among different regions, and the difference between provinces was more than $30 \%$. Shu (2015) pointed out that the average level of technical efficiency was not high in China's thermal power industry, and that there were larger differences between the calculated values of the technical efficiency in different regions. A study by Chengxuan (2016) showed that there were different average levels and changing trends among different size groups in various industries of the Chinese state-owned industrial sector. Different regions have different levels of economic development, which can lead to the differences in the clustering effects of resources, human resources and enterprises, thus affecting their ability and the environment for business operations, thereby affecting their technical efficiency. Based on that, this article proposes the following theoretical assumption:

H6: Regional differences have a positive effect on military technical efficiency.

\section{Study design and data description}

In an effort to analyse the technical efficiency of listed Chinese military companies, this article adopts the (SFA method). This method divides the error items into two types: modelling error and non-efficiency error in model setting, so as to reflect the actual technical efficiency of enterprises more effectively (Aigner, 1976). In addition, the SFA method can also test the hypothesis of the parameters of the frontier function and the technical inefficiency function. In view of this, based on panel data of listed companies in the military industry from 2010 to 2015, we use the SFA method to model the technical efficiency of the top 10 military industrial enterprises in China, and reveal and discuss the influencing factors and impact effects of the non-technical efficiency of military industrial enterprises.

\section{Research methods}

According to the most commonly used SFA, the logarithmic production function of Cobb-Douglas is used to analyse the technical efficiency and influencing factors of Chinese military industrial enterprises. The specific research model is as follows:

$$
\begin{aligned}
& \operatorname{In}\left(Y_{i t}\right)=\beta_{0}+\beta_{1} \operatorname{In}\left(L_{i t}\right)+\beta_{2} \operatorname{In}\left(K_{i t}\right)+\left(\mathrm{v}_{i t}-u_{i t}\right) \\
& m_{i t}=\delta_{0}+\delta_{1}\left(\text { Top }_{i t}\right)+\delta_{2}\left(\text { Share }_{i t}\right)+\delta_{3}\left(\text { Asset }_{i t}\right) \\
& +\delta_{4}\left(\text { Scale }_{i t}\right)+\delta_{5}\left(\text { Educa }_{i t}\right)+\delta_{6}\left(\operatorname{Re} \text { gion }_{i t}\right)+\omega_{i t} \\
& \gamma=\frac{\delta_{u}^{2}}{\delta_{u}^{2}+\delta_{v}^{2}}
\end{aligned}
$$

Where $i$ and $t$ denote the $i$ th military enterprise and the $t$ th year, respectively. In Equation 1, $\mathrm{Y}_{\mathrm{it}} \mathrm{L}_{\mathrm{it}}$ and $\mathrm{K}_{\mathrm{it}}$ respectively, represent the operating profit, fixed assets and staff number of the ith enterprise in year $t . \beta_{1}$ and $\beta_{2}$ are the elastic coefficients corresponding to the fixed assets and the number of employees, respectively. $v_{i t}-u_{i t}$ is the error term of the composite structure, where $v_{i t}$ denotes the modelling system error, obeying the normal distribution $N\left(0, \delta_{v}^{2}\right)$; it denotes the technical inefficiency term of the non-negative random variable, subject to the censored normal distribution $N\left(\mathrm{~m}_{\mathrm{it}}, \delta_{v}^{2}\right)$ and the two are independent of each other. In Equation 2, Top3, Share, Asset, Scale, Educa and Region, respectively, represent the degree of ownership concentration, the proportion of state-owned major shareholders, the turnover rate of assets, the scale of enterprises, the level of staff education and the region. $\delta_{1}, \delta_{2}, \delta_{3^{\prime}}, \delta_{4}, \delta_{5}$ and $\delta_{6}$ are the coefficients of influence of the six variables on technical inefficiency.

\section{Sample source}

The research sample is from the listed companies of 'Top Ten' in the Huachen Information Database in Shanghai and Shenzhen stock exchanges. Taking into account the data validity, we excluded the military industrial enterprises that had financial anomalies during 2010-2015. After making the 
above screening, we selected the remaining 53 listed companies in the military industry as the research object with a total of 318 observations.

\section{Variable selection}

In terms of input-output variables, this article selects operating income as the output variable, using fixed assets and the number of employees as input indicators. In terms of nonefficiency factors, this article selects six relevant variables, namely ownership concentration, the proportion of stateowned large shareholders, asset turnover, the size of the enterprise, staff education levels and regional differences. Shareholding concentration is the shareholding ratio of the top three shareholders; the shareholding percentage of the state-owned major shareholders is the proportion of stateowned shareholdings in the top 10 shareholders. Asset turnover ratio is the ratio of operating income to total assets. Employee education level is the proportion of employees with bachelor degree or above. The region is the place of registration of the enterprise and with reference to 'the People's Republic of China National Economic and Social Development Statistical Communique'. The regions are divided into the western, north-eastern, central and the eastern region, respectively, assigned to 1, 2, 3 and 4 . In addition, given the panel data used in this article, time variables $(T=$ year +1$)$ would be introduced into the model. In summary, the variables selected in this article are shown in Table 1.

\section{Empirical analysis}

\section{Influencing factors multicollinearity analysis}

If there is multicollinearity in the factor in terms of inefficiency, this can lead to deviations in data findings. Therefore, this article uses SPSS to test the data of inefficiency items before using Frontier 4.1 to ensure that the results of the analysis are accurate. The condition index $\mathrm{CI}=\sqrt{\frac{\lambda_{\max }}{\lambda}}$ ) is greater than 15 , indicating that there may be multicollinearity problems in the model. Through calculation and analysis, the condition index of the influencing factors studied in this article is less than 15 , indicating that there is no collinearity problem in the model (as shown in Table 2).

\section{SFA model analysis}

Based on the panel data, this article uses the Frontier 4.1 program to analyse the first two steps of the least squares' method. The program is also used to iterate the maximum process, the maximum likelihood estimation (MLE) of the model parameters and the results of the correlation test. In addition, the descriptive statistics on the technical efficiency of each of the 53-sample military industrial enterprises for each of the years 2010-2015 are made. According to the SFA model estimation, the results are shown in Table 3.

Firstly, the article selected some influencing factors, and thus, the result of the estimated parameter $(\gamma=0.7849)$ indicates that $78.49 \%$ of those influencing factors (dependent value) are explained in the frontier production function. The uncontrollable factors of the noise only account for a small proportion, so the use of the SFA model for analysis in this article is in the right direction.

Secondly, we can see from the analysis of parameter results that $\beta_{0}, \beta_{1}$ and $\beta_{2}$ all pass the significance $t$ test under $1 \%$. According to the regression results, we can establish the production function of sample enterprises as follows in Equation 4:

TABLE 1: Variable description.

\begin{tabular}{|c|c|c|c|}
\hline Variable type & Name & Variable name & Variable description \\
\hline \multirow[t]{2}{*}{ Output variables } & Operating income & $Y$ & The current business income of the logarithm \\
\hline & Fixed assets & L & $\begin{array}{l}\text { The logarithm of the mean of fixed assets at the end of the period and the beginning of the } \\
\text { period }\end{array}$ \\
\hline \multirow[t]{4}{*}{ Invest in variables } & Number of employees & $\kappa$ & The total number of employees working in the company that year \\
\hline & Ownership concentration & Top3 & Shares held by the top three shareholders \\
\hline & $\begin{array}{l}\text { State-owned major shareholder } \\
\text { shareholding ratio }\end{array}$ & Share & The proportion of state-owned shares held by the top 10 largest shareholders \\
\hline & Enterprise size & Scale & The mean of the total assets at the end of the period and the beginning of the period \\
\hline \multirow[t]{3}{*}{ Affect variables } & Employee education level & Education & In-service staff bachelor degree or above ratio \\
\hline & Area & Region & $\begin{array}{l}\text { Registered staff, the western, north-eastern, central and eastern regions were assigned } 1,2,3 \\
\text { and4, respectively }\end{array}$ \\
\hline & Time variable & Year & 2010 recorded as $T=1$, followed by analogy \\
\hline
\end{tabular}

TABLE 2: Multicollinearity diagnosis table.

\begin{tabular}{|c|c|c|c|c|c|c|c|c|c|}
\hline Dimension & Eigenvalue & $\begin{array}{c}\text { Condition } \\
\text { index }\end{array}$ & (Constant) & $\begin{array}{l}\text { Equity set } \\
\text { moderate }\end{array}$ & $\begin{array}{l}\text { State-owned major } \\
\text { shareholder } \\
\text { shareholding ratio }\end{array}$ & $\begin{array}{c}\text { Asset } \\
\text { turnover }\end{array}$ & $\begin{array}{l}\text { Enterprise } \\
\text { size }\end{array}$ & $\begin{array}{l}\text { Employee education } \\
\text { level }\end{array}$ & Region \\
\hline 1 & 5.322 & 1.000 & 0.00 & 0.00 & 0.00 & 0.01 & 0.01 & 0.01 & 0.00 \\
\hline 2 & 0.855 & 2.495 & 0.00 & 0.00 & 0.00 & 0.04 & 0.83 & 0.00 & 0.00 \\
\hline 3 & 0.364 & 3.822 & 0.00 & 0.00 & 0.00 & 0.83 & 0.08 & 0.11 & 0.01 \\
\hline 4 & 0.237 & 4.737 & 0.01 & 0.02 & 0.06 & 0.07 & 0.06 & 0.62 & 0.01 \\
\hline 5 & 0.155 & 5.861 & 0.00 & 0.01 & 0.03 & 0.01 & 0.00 & 0.21 & 0.76 \\
\hline 7 & 0.027 & 14.093 & 0.68 & 0.79 & 0.08 & 0.01 & 0.00 & 0.00 & 0.10 \\
\hline
\end{tabular}


$Y=15.8735 L^{0.2373} K^{0.3382}$

[Eqn 4]

Subsequently, the fixed assets elasticity coefficient of military industrial enterprises of $\left(\beta_{1}=0.2373\right)$ means that the average operating profit of enterprises increases by 0.2373 percentage points for every unit of fixed assets. In addition, the elasticity coefficient $\left(\beta_{2}=0.3382\right)$ of the number of employees implies that for every increase of one employee, the profits of the business will also increase by 0.3382 percentage points.

Thirdly, the elasticity coefficients of input variables are all seen to be positive, and its sum is 0.5755 , which is less than 1 . This implies that the output of the military industrial enterprises will increase if the input of factors of production increase, but the production process is presenting a scale of decreasing returns.

\section{Analysis of influencing factors of enterprise efficiency}

According to Table $3, \delta_{1}$ and $\delta_{2}$ did not pass the significance test at $1 \%$ level. $\delta_{1}=-0.6896$ signifies that there is a positive correlation between ownership concentration and the technical efficiency of military industrial enterprises, but not significant. $\delta_{2}=0.4847$ demonstrates that the share of stateowned major shareholders is inversely related to the technical efficiency of military industrial enterprises, but not significant. $\delta_{3^{\prime}} \delta_{4^{\prime}} \delta_{5}$ and $\delta_{6}$ all passed the significance test at the $1 \%$ level. Among them, $\delta_{3}=-0.9974$ indicates that the asset turnover rate and military industrial technology efficiency are positively correlated. Thus, the improvement of military assets turnover rate can promote the improvement of technical efficiency. $\delta_{4}=-3.84 \mathrm{E}-11$ indicates that the scale of enterprises and the technical efficiency of military industrial enterprises were positively correlated.

Among the 53 sample military industrial enterprises, the technical efficiency of enterprises increased because of an increase in scale efficiency. There was also a positive correlation $\left(\delta_{5}=-1.4440\right)$ between staff education and the

\begin{tabular}{lcccc}
\hline \multicolumn{5}{l}{ TABLE 3: Stochastic frontier analysis parameters estimation results. } \\
\hline $\begin{array}{l}\text { Parameter } \\
\text { estimates }\end{array}$ & $\begin{array}{c}\text { Coefficient } \\
\beta_{0}\end{array}$ & Standard error & T statistics & $\begin{array}{c}\text { Likelihood } \\
\text { estimates }\end{array}$ \\
$\beta_{1}$ & 0.23735 & 0.4630 & $34.2810^{*}$ & - \\
$\beta_{2}$ & 0.3382 & 0.0225 & $10.5658^{*}$ & - \\
$\delta_{0}$ & 3.8162 & 0.0456 & $7.4154^{*}$ & - \\
$\delta_{1}$ & -0.6896 & 0.2908 & $13.1231^{*}$ & - \\
$\delta_{2}$ & 0.4847 & 0.4417 & 1.0974 & - \\
$\delta_{3}$ & -0.9974 & 0.0441 & $-22.5933^{*}$ & - \\
$\delta_{4}$ & $-3.84 \mathrm{E}-11$ & $1.80419 \mathrm{E}-12$ & $-21.2638^{*}$ & - \\
$\delta_{5}$ & -1.4440 & 0.2757 & $-5.2368^{*}$ & - \\
$\delta_{6}$ & -0.1598 & 0.0404 & $-3.9542^{*}$ & - \\
$\sigma^{2}$ & 0.5956 & 0.0445 & $13.3875^{*}$ & - \\
$\gamma$ & 0.7849 & 0.0546 & $14.3857^{*}$ & - \\
Log likelihood & - & - & - & -325.44403 \\
function & & - & & - \\
LR test of the & - & - & & 246.00853 \\
one-sided error & & & & \\
\hline
\end{tabular}

Note: Element output elasticity analysis.

$*$, significant at $1 \%$ level. technical efficiency of military ind ustrial enterprises, meaning that the level of staff education affects the technical efficiency of enterprises. The regional differences correlated positively $\left(\delta_{6}=-0.1598\right)$ with military industrial enterprises indicating that regional differences (geographical location of the east) affect the technical efficiency of military industrial enterprises.

From the results above, we notice that among the six influential factors, the regional differences have the most obvious impact, followed by staff education and asset turnover. This implies that military and industrial enterprises in different regions should better support each other, and at the same time, they should strengthen staff training and improve asset turnover.

\section{Enterprise efficiency analysis}

Results from Table 4 indicates that the average efficiency (0.2697) of the 53 sample enterprises in 2010-2015 showed a low overall efficiency value, and the gap between the analysed technical efficiency of military industrial enterprises was too large. However, from the perspective of the dynamic development of the technical efficiency of military industrial enterprises, the average value of technical efficiency in 2010-2015 has been on an upward trend, with a marked increase (calculated value of 0.311648 ) in 2015, indicating a slightly lower technical efficiency of military industrial enterprises over time.

\section{Conclusion}

In this article, we used the SFA to measure the technical efficiency of 53 listed companies affiliated to the 'Top Ten' in China from 2010 to 2015, analysed the six influencing factors (ownership concentration, shareholding of state-owned shares, asset turnover, enterprise size, staff education and regional differences) and concluded the following:

The overall technical efficiency of the listed companies affiliated with the 'Top Ten' military groups is not high, and the technical efficiency of most enterprises is extremely low, though quite different from one another.

The difference in geographical location, the level of staff education and the turnover rate of assets have an important and significant positive impact on the technical efficiency of military industrial enterprises.

The improvement of the scale of enterprises within a certain range can promote the improvement of technical efficiency.

Ownership concentration has a positive effect on technical efficiency, but its influence is not significant.

TABLE 4: Descriptive statistics of efficiency of military industrial enterprises in each sample year 2010-2015.

\begin{tabular}{lcccccc}
\hline Index & $\mathbf{2 0 1 0}$ & $\mathbf{2 0 1 1}$ & $\mathbf{2 0 1 2}$ & $\mathbf{2 0 1 3}$ & $\mathbf{2 0 1 4}$ & $\mathbf{2 0 1 5}$ \\
\hline Max & 0.000508 & 0.000292 & 0.060595 & 0.057863 & 0.061439 & 0.008766 \\
Min & 0.934980 & 0.928226 & 0.887461 & 0.888372 & 0.905298 & 0.906647 \\
Mean & 0.231519 & 0.269907 & 0.267422 & 0.264711 & 0.272760 & 0.311648 \\
Std. & 0.209778 & 0.236963 & 0.207624 & 0.203279 & 0.208938 & 0.244306 \\
\hline
\end{tabular}

Max, maximum; Min, minimum; Std., standardised. 
The proportion of state-owned large shareholders has a negative impact on technical efficiency, but its effect is not significant.

\section{Implications}

The low technical efficiency of the military industries has a major role in the development of civil-military enterprises in China. Therefore, a new standard is required to analyse China's military industrial abilities. Even though there has been an increased funding for the production of weapons from domestic military enterprises, the latest military industrial reforms, in contrast to the multiple failed efforts of the 1980s and 1990s, have brought about changes in institutions and incentives at both the government and the enterprise levels of operation in China's industrial system. These policy changes have produced successes as the financial strength of military firms improves (Medeiros, 2004).

Nevertheless, even though the differences in regional locations, staff educational levels and the turnover rate of assets had an important and significant positive impact on the technical efficiency of military industrial enterprises, much more research is needed to track these trends and, most importantly, to understand how fast and why these improvements are occurring. Similar phenomena have occurred in military industries around the world. Yet, further research is needed to determine the relative influence of the recent organisational reforms on the output and operations of China's military enterprises. Also, better metrics are needed to measure the relative benefit of civil-military integration on the capabilities of military enterprises.

China's military industries will increasingly play a pivotal role in the future direction and military competence of the civil-military integration. Thus, the issue of China's military industry is a crucial and increasingly important variable in the complex and evolving equation in the modernisation of civil-military integration.

\section{Suggestions}

Based on the above analysis, this article aims to improve the technical efficiency of military industrial enterprises in the context of military-civilian integration, the following related suggestions are made:

\section{Perfecting social networks and improving enterprise innovation ability}

Social network is based on the form of social organisation formed by the interconnection of network nodes. The construction and perfection of social network are beneficial to the sharing of resources, exchange of information and diffusion of technology among network nodes, so that it is important to optimise resources and improve technical efficiency effect. Therefore, in the era of information-based internet, the exchange of information has become very convenient. The military industrial enterprises in different regions should construct social networks that are closely linked with each other and constantly improve them so that military industrial enterprises may enjoy richer resource sharing, faster information dissemination, more efficient technical exchange, and ultimately to promote business innovation and technical efficiency.

\section{Strengthen staff training and enhance the comprehensive ability of qualified personnel}

To meet the business needs of enterprises and nurturing talent, staff training is essential. The purpose of staff training is to promote staff knowledge updates, skills improvement and development. The purpose of the training is also to improve employee motivation, attitude and behaviour, so as to improve the efficiency of the organisation and organisational goals. Military personnel need professional personnel, and the professional skills of military personnel determine the level of technological innovation and technological innovation efficiency. However, at present, the general situation of military industrial enterprises is that the supply of ordinary low-end personnel is over-supply and the supply of high-end professionals is inadequate, and the military industrial enterprises have a structural gap in the supply of qualified personnel. In the future, the state and military industrial enterprises should deepen education reform, increase the supply of professionals in military industrial enterprises, upgrade the quality of qualified personnel in military industrial enterprises and increase their influence on the efficiency of technological innovation in military industrial enterprises. In addition, an unreasonable talent structure will lead to structural problems in the quality of military industrial enterprises' supply of products. The shortage of high-end professionals will inevitably lead to the shortage of high-end products, and the excess supply of ordinary employees will lead to the supply of low-end products. In future, the military industrial enterprises should actively promote China's supply-side structural reform policies, on one hand, to actively introduce and train highend professionals, expanding the proportion of professionals in the enterprise. However, military and industrial enterprises should also be reasonable in the allocation of innovative activities in proportion to the professionals and general staff ratio. As the employee structure directly determines the product structure, the military industry should adjust the product strategy according to the market demand, timely adjust the personnel supply structure according to the changes in the product demand structure, and ultimately upgrade the enterprise from the aspects of improving the quality of the talent supply and optimising the supply structure of the qualified personnel.

\section{Rational use of capital to enhance the competitiveness of enterprises}

Total asset turnover reflects the management of the total assets of the enterprise quality and efficiency, as well as business sales in the market competitiveness. Therefore, military industrial enterprises need to accurately locate the product market, improve sales channels and make full use of existing assets to promote revenue maximisation. 


\section{Deepen the reform in an all-round way and give full play} to the leadership of the board of directors

The board of directors is the leading group of enterprises, and the factors such as the scale, structure, remuneration incentives, the appointment of independent directors and the qualifications of independent directors make a substantial contribution to the improvement of the governance performance of the board of directors, while the governance performance of the board of directors directly affects the business decision-making and efficiency. In the context of military and civilian integration, military industrial enterprises should continue to deepen the reform, set up a reasonable and efficient board of directors, and lead the continuous improvement of technological efficiency.

\section{Encourage staff innovation and enhance innovation awareness}

As China's economy continue growing at a swift pace, China already ranks among the largest powers in the world (Morrison, 2018). Therefore, the government attaches more and more importance to the building of the national defence. The costs of military expenditures in the fiscal investment have been increasing year by year, trying hard to support the national defence strength and economic strength for development (Cordesman, 2016). However, some military industrial enterprises in China are only vaguely aware of the efficiency of technological innovation and lack the high-end military products of independent innovation (Lin, Wang, Zhou, Sun, \& Wei, 2011). In addition, because of the lack of adequate information communication between military and industrial enterprises, there are more and more R\&D between military and industrial enterprises, resulting in inefficient technology development. Therefore, all military industrial enterprises should strengthen their awareness of innovation, and enterprises should fully communicate with each other to eliminate the phenomenon of information asymmetry, avoid duplication of $R \& D$, and enhance the efficiency of technological innovation. Moreover, companies should regularly organise employees to learn not only to enhance the professional skills of employees but also to strengthen staff awareness of innovation.

\section{Reasonably choose the area and optimise the regional resource allocation}

Although the current rate of economic development in the eastern part of China, as a whole, is faster than that in the west, the military industrial enterprises in the east are affected by economic development and market demand, and their technological innovation efficiency is also higher than that in the western part (Huang, Ma, \& Sullivan, 2010). Therefore, China's military industrial enterprises should reasonably choose their business addresses and rely on the advantages of regional resources to enhance the efficiency of technological innovation.

\section{Acknowledgements}

The authors thank the Social Science Funding Project of the Jiangsu Province (No. 18GLB024) for providing funding for this study.

\section{Competing interest}

The authors have declared that no competing interests exist.

\section{Authors' contributions}

L.M. was responsible for formal analysis and supervision. O.A.A. was responsible for methodology, formal analysis, writing and correspondence. M.Z. was responsible for review and editing. K.G. was responsible for software. M.Z. was responsible for methodology and original draft preparation. L.X. was responsible for data collection and literature review. S.H. was responsible for data collection.

\section{Ethical consideration}

This article followed all the ethical guidelines for a reseach project without direct contact with human or animal subjects.

\section{Funding information}

This study was funded by the Social Science Funding Project of Jiangsu Province (No. 18GLB024).

\section{Data availability statement}

Data sharing is not applicable to this article as no new data were created or analysed in this study.

\section{Disclaimer}

The views and opinions expressed in this article are those of the authors and do not necessarily reflect the official policy or position of any affiliated agency of the authors.

\section{References}

Afriat, S.N. (1972). Efficiency estimation of production functions. International Economic Review, 13(3), 568-598. https://doi.org/10.2307/2525845

Aigner, D. (1976). Formulation and estimation of stochastic frontier production function models. Journal of Econometrics, 6(1), 21-37. https://doi.org/10.1016/ 0304-4076(77)90052-5

Baijie, W., \& Aijin, L. (2016). Calculation of the efficiency of military-civil-integration enterprises and its influencing factor - Evidence from listed companies of the 'Top Ten Military Groups' in China. Science and Technology Management Research, (23), 67-73.

Bao-Bao, J., \& Yan-Ling, X. (2011). Performance evaluation and influencing factors of China's food and beverage industry - DEA-tobit model based on SORM-BCC and Malmquist. Shanghai Economic Research, (9), 71-84.

Chengxuan, L. (2016). Research on the technical efficiency of Chinese state-owned industrial enterprises under the condition of large-scale heterogeneity. Dongbei University of Finance and Economics, 9(4), 97-113.

Chunyan, L., Chen, Y., \& Zhaoyang, Z. (2014). Region differences and convergence of China's technical efficiency. Economic Geography, (05), 116-122.

Cordesman, A.H. (2016). Estimates of Chinese military spending. Retrieved from http://www.csis.org/analysis/estimates-chinese-military-spending

Farrell, M.J. (1957). The measurement of productive efficiency. Journal of the Royal Statistical Society. Series A (General), 120(3), 253-290. https://doi.org/ $10.2307 / 2343100$

Feng, T., Jian-wan, G., \& Shun-xian, Y. (2008). Technical efficiency of power generation industry and its influencing factor during power system transition. China Industria Economics, (1), 68-76.

Hang, Y., Guang, S., \& Bai-zhou, L. (2013). Analysis and evaluation of independent ability of military enterprise based on entropy-topsis model. Operation Management and Management, (3), 139-154.

Huang, N., Ma, J., \& Sullivan, K. (2010). Economic development policies for Central and Western China. The Magazine of US-China Business Council, p. 66

Jeong, K.-I., Lee, J.-D., \& Lee, C. (2010). Profitability gains of Korean defence firms technological progress or cost shifting? Asian Journal of Technology Innovation, 18(2), 219-239. https://doi.org/10.1080/19761597.2010.9668699 
Jianshan, H., \& Chunmi, L. (2009). Ownership structure, technical efficiency and corporate performance: An empirical study on Chinese listed companies. Economica Review, (3), 77-82.

Jianyue, J., \& Kongjiao, K. (2013). A study on efficiency of agriculture in China based on DEA-Tobit two-stage model. Journal of Ocean University of China, (2), 59-62.

Jiong, Z. (2012). An empirical study on the relationship between equity structure and business performance of military listed companies. East China Economic Science, (1), 110-112.

Jiong, Z., \& Yinning, W. (2012). Speeding up the mechanism of military enterprise stock reform and countermeasures. Science and Technology Progress and Countermeasures, (2), 91-94.

Jun, X. (2004). Military technology innovation. Modern Economics Research, (11), 65-67.

Kaiwen, J., \& Fanbin, K. (2014). Technical efficiency measurement and promotion of bio-agriculture listed companies in China based on three-stage DEA model. Chinese Rural Economy, (8), 42-57.

Li, P.C., \& Chao-feng, H. (2014). Convergence analysis on the fusion of military and civilization in strategic emerging industries - A case study of nuclear energy industry. Science and Technology Progress and Policy, (22), 97-101.

Lin, G.C.S., Wang, C.C., Zhou, Y., Sun, Y., \& Wei, Y.D. (2011). Placing technological innovation in globalising China: Production linkage, knowledge exchange and innovative performance of the ICT industry in a developing economy. Urban Studies, 48(14) 2999-3018. https://doi.org/10.1177/0042098010396232

Lingxiao, Y. (2012). Research on the relationship between governance structure and technological innovation in Chinese military enterprises. Science and Technology Progress and Policy, (4), 70-74.

Medeiros, E.S. (2004). Analyzing China's defense industries and the implications for Chinese military modernization. Santa Monica, CA: RAND.

Mei, Z. (2013). Research on innovation performance evaluation of high-tech enterprises based on DEA-Tobit Model. Quest, (12), 31-33.

Min, L., \& Haojie, C. (2016). Comparative analysis of management efficiency of listed military industrial enterprises from the perspective of military and civilian integration. Jiangxi Social Sciences, (2), 188-193.

Morrison, W.M. (2018). China's economic rise: History, trends, challenges, and implications for the United States. Retrieved from www.crs.gov.

Qian, Z., Xiuyun, Y., Yuan, L., \& Yining, Z. (2015). Technical efficiency of China's cultura and creative industries: A study of industry differences and influencing factors. Economic Exploration, (11), 88-97.

Qunying, L. (2009). Equity structure and economic performance of the relationship between Nanjing University of Aeronautics and Astronautics. Nanjing: Transactions of Nanjing University of Aeronautics and Astronautics.
Ran, L., \& Yue, C. (2015). Technical efficiency, firm size and industrial transformation: Observations from energy sources. Reform, (6), 59-62.

Sheng-sheng, C., \& Ye, L. (2014). Construction of the theoretical model of military industrial transformation and upgrading ability. Science and Technology Progress and Countermeasures, (4), 80-83.

Shu, L. (2015). Technical efficiency analysis of thermal power industry based on stochastic frontier production function and provincial panel data. Microeconomic Research, (10), 14-23.

Tao, S. (2015). Research on mechanism of technological accumulation, capability structure and sustainable growth of military and commercial integration enterprise - Based on the perspective of technology transfer. Science and Technology Progress and Policy, (18), 109-113.

Wenjun, L., \& Bing, X. (2016). Research on technology efficiency of Chinese iron and steel listed companies based on carbon emissions. China Population Resource and Environment, 10-13.

Xiangyin, L., Zhonghua, L., \& Ting, Y. (2016). Measurement and policy research on technical efficiency of Chinese eco-agriculture listed companies - Empirical analysis based on panel data. Journal of Soft Science in China, (7), 162-171.

Yaun-jun, Z., \& Lin, L. (2016). Analysis of efficiency allocation of science and technology resources of private-owned military enterprises based on Malmquist index. National Defence Science and Technology, (8), 72-80.

Ying, Z., \& Po, C. (2016). Performance evaluation and influencing factors of China's sports industry listed companies: A DEA-Tobit empirical study based on panel data. Acta Metallurgica Sinica, (12), 34-41.

Yongmei, W., Qinliang, T., Chong, Z., Yanming, D., \& Yuan, L. (2015). Technical efficiency of wind power industry and its influencing factors. China Science and Technology Forum, (6), 76-81.

Yuanyuan, Y. (2013). Research on technology efficiency and influencing factors of listed companies in Chinese automotive industry. Shandong Social Sciences, (2) 165-169.

Yuhai, L., \& Kun, L. (2010). Efficiency characteristics of listed companies in China's wine industry and its influencing factors: A two-stage model based on DEA-Tobit Finance and Economics, (2), 1-6.

Zhijun, Y., Changhui, Y., Zhanglin, P., \& Keyu, Z. (2015). Research on efficiency evaluation of technological innovation activities in military enterprises in Anhui Province. Science and Technology Management Research, (20), 62-66.

Zhonghua, Z., \& Xiaofeng, J. (2013). Research on the impact of technology spillovers and government subsidies on technological innovation activities in military enterprises - An empirical analysis on China's listed military industrial enterprises. Soft Science in China, (10), 124-133.

Zhongyong, Y. (2010). X-efficiency: Empirical analysis of Chinese listed military and industrial enterprises. National Defence Science and Technology, (1), 33-42. 